\title{
MĀORI RESISTANCE IN NEW ZEALAND FEATURE FILM HISTORY
}

Jani Katarina Taituha Wilson*

\begin{abstract}
This article draws on the textual analysis of films that produced three distinctive collective resistances across New Zealand film history. Hāhi Ringatū leaders protested to the Chief Censor about the portrayal of their beloved prophet Te Kooti in the Te Kooti Trail. The director was forced to make changes, and delayed the release. Later, after decades of support, Te Arawa were collectively absent from film production for nearly 40 years after director Alexander Markey insulted their manaakitanga with a series of misdemeanours during the production of Under the Southern Cross. Lastly, my Ngāti Kawa whānau refused to respond to a screening of The Seekers, utilising silence to show their resistance to such portrayals of Māori. I briefly explore silence as an unusual but valid response to film, and I counterpoint the gross stereotypes portrayed in The Seekers with mātauranga Māori concepts the filmmaker may have based the characterisations on.
\end{abstract}

\section{Keywords}

silence, resistance, counterpoint, film history

* Ngāti Awa/Ngā Puhi/Ngāti Hine. Lecturer, Māori Media and Creative Writing, Te Ara Poutama, Department of Māori and Indigenous Development, Auckland University of Technology, Auckland, New Zealand.

Email: jani.wilson@aut.ac.nz

DOI: 10.20507/MAIJournal.2018.7.1.3 


\section{Introduction}

resistance

ri'zist(ə)ns/

noun

The refusal to accept or comply with something.

Synonyms: opposition to, hostility to, aversion to, refusal to accept, unwillingness to accept, disinclination to accept, reluctance to accept, lack of enthusiasm for.

Historically, Māori resistance-active and passive-has been accompanied by layers of sound. Static photos of Māori resistance capture protesters with mouths in mid-motion; some have instruments and others megaphones. Merata Mita's protest/resistance films Bastion Point: Day 507 (Mita, 1980) and Patu! (Mita, 1982) convey the multiple levels of sound long associated with Māori resistance: chanting, yelling, haka, gumboots on tarmac, helicopters, megaphones, sniffing hupe, and such. Sound is a fundamental component in hîkoi demonstration. Haka, which hinges on protest and voicing issues, relies on the voice, and sounds made on the body. During a wānanga in 2010, my Ngāti Kawa whānau refused to verbally respond to a screening of The Seekers (Annakin, 1954), preferring instead to prepare the wharenuiour makeshift cinema-for the next hui. The refusal to conform, discomfiture and lack of enthusiasm for the film were performed through silence. A difficulty this article begins with is the justification of silent Māori resistance. Is silent Māori resistance possible? If so, what does it serve? How else has resistance been exercised in New Zealand film history?

Kapa haka stalwart Ngoi Pewhairangi (2008) spoke about being involved with Ngā Tamatoa and the Te Kotahitanga movement in a non-verbal protest at Waitangi one year, claiming loss of land and culture was nothing to celebrate. There was no shouting or calling, "but every time [Prime Minister] Muldoon began to speak, we would clap. That was our way of disrupting ... and [telling] our people to boycott [Waitangi celebrations]" (as cited in Ka'ai, 2008, p. 53). Clapping to muffle a speaker is a non-verbal response, but not silent. In the mid-1980s Mead (1984) wrote about the audience's physical response to haka. He said haka "[fills] one with awe (wehi) so that the spine tingles, one's body hair may straighten up, and the whole-body trembles with [ihi] excitement. . . There is authority (wana) in the performance-class, integrity, confidence, and unquestioned competence" (p. 24).

Ihi, wehi and wana are the fundamental energising values of haka that are causative of the viewer's physical reaction to haka performance. If the viewer's wairua is not stirred, Mead (1984) stressed, the performance is "likely to receive a stony silence” (p. 24). Mead's reference to "stony silence" is important here, as it indicates that silence can be as offensive as loud heckling and insults, a kind of passive aversion or resistance to the performance. As I write this, Ngāi Taiwhakāea-my predominant hapū on my koroua's side-are engaged in a silent protest on our papakāinga in Pāroa, Whakatāne. Among other issues, the protest is against the request to pay for our land-seized under the Recreations Acts in the 1950s_as it is now up for sale by the Whakatāne Golf Club for well in excess of $\$ 600,000$. The silent presence of our whanaunga planted on the corner of Golflinks and Taiwhakāea Roads is an important reminder of the injustices committed against our iwi over the decades since the raupatu whenua. In these cases, silence should not be mistaken for absence; the iwi have made an active choice to disengage from conversations deemed unnecessary (Rich, 1978/1993; Visweswaran, 1994). Silence indeed has presence.

What follows is an exploration of documented instances of resistance to film in New Zealand film history, and I weave in a new hue, which is the silent response to film by my Ngāti Kawa whānau. It could simply be that the whānau chose to be silent because they 
considered The Seekers a "bad film". However, throughout the wānanga there were other films this rōpu viewed and did not enjoy, for a range of reasons, including The King Boys (Clark, 2006) and Hawaikii (Jonathan, 2006), and they were frank about it. The silent response is the exceptional circumstance this article underlines.

This article is organised into three distinct sections, and includes a substantial glossary. The first section is devoted to unpacking two relatively well-known instances of resistance in New Zealand film history, when Māori resisted film in the silent film era. The second briefly focuses on the audience's silent resistance to The Seekers, the response this article hinges on. In the last section, I utilise Edward Said's (1993) contrapuntalism or counterpoint approach to analyse The Seekers in more detail, and to postulate why silent resistance was the chosen response. This kind of examination of, and research into, New Zealand film history is useful because it weaves a Māori worldview into a primarily non-Māori discipline. It introduces fundamental mātauranga Māori concepts that would otherwise continue to be omitted from New Zealand film history. There is much room for research in Māori screen studies in the future.

\section{Resistance in New Zealand film history}

Māori were pivotal to New Zealand's earliest cinematic era, as is evident in titles such as Loved by a Maori Chieftess (Méliès, 1913c), How Chief Te Ponga Won His Bride (Méliès, 1913b), Hinemoa (Méliès, 1913a; Tarr, 1914) and The Romance of Hinemoa (Pauli, 1927). The titles show that the films are reconstructions of iwi stories, albeit Victorian romance versions of them. As was customary in filmmaking during the silent era, and elemental to New Zealand film's international commercial viability, many aspects of the character and narrative arcs were manufactured to satiate an international audience who had a strong desire to see the enigmatic native Pacific cultures in action. This was certainly the case in The Te Kooti Trail (Hayward, 1927), based on a very important leader, land defender, pioneer of the Hāhi Ringatū and prophet, Te Kooti Te Turuki Arikirangi.

\section{Film synopsis: The Te Kooti Trail}

The Te Kooti Trail (Hayward, 1927) is set in Whakatāne during the mid-1860s to the early 1870 s, and was shot on location in the same town. It follows fictional character Eric Mantell, who is sent to New Zealand from England to fight in the wars as punishment for a petty crime. He leaves behind his beloved Alice, promising to return a war hero. Mantell enlists in the British constabulary under Gilbert Mair, in pursuit of the influential Māori leader and guerrilla war fighter, Te Kooti. Te Kooti and his men launch an attack on Mair, Jean Guerin and the Ngāti Pūkeko allies, but he evades capture. Te Kooti continues to elude the constabulary for another year, until the persistent Mair finally captures him, and-after 20 years of pursuit-brings him to justice.

\section{Ringatū resistance}

The Hāhi Ringatū protest against The Te Kooti Trail's release was the first noted resistance by Māori against film in New Zealand. The Hāhi Ringatū is a church founded by Te Kooti in the late 1860s and still in existence today, predominantly in the Eastern Bay of Plenty. The Ringatū faith-literally, ringatū means upraised hand-was so named because of the multiple references in the Bible to lifting one's hands in prayer. After Ringatū disciples recite their long passages of Bible by memory, they end with a prayer, then raise their right hand at the same time as they say "kororia ki tou ingoa tapu" and "amine". Ringatū pivots equally on long passages of biblical scripture translated into te reo Māori, committed to memory and 
sung, and defence of Māori land rights. Prior to The Te Kooti Trail's release, Acting Minister of Internal Affairs Maui Pomare requested a special screening of The Te Kooti Trail for Ringatù elders and other Māori ministers of Parliament (MPs). The Ringatū leaders were appalled by misrepresentations Hayward-a Pākehā director-conveyed in the film. The intertitles accused Te Kooti of fake miracles and false doctrine, which was an attack on their faith (Binney, 1995). In addition to condemning Te Kooti, there were misrepresentations of Peka Makarini, a tippuna to many in the Tùhoe arm of the Ringatū Church. Colonel Gilbert Mair's dialogue referred to Makarini as a "bloody monster", the "torture master" and the "stage manager of miracles", and demonised his half-castedness (Blythe, 1994, p. 37). The Ringatū were anxious that audiences would condemn their whanaunga. Historian Judith Binney's (1995) archival research and one-onone interviews with Te Kooti's descendants and present-day Ringatū disciples show that Hayward's assumption that the Ringatū were upset because they were not involved in the production were false. Their main concern was that their beloved ariki had been represented as a "false prophet" (Binney, 1995, pp. 551-555).

The Māori MPs encouraged the Ringatū leaders to take their complaints to the New Zealand's Chief Censor, W. A. Tanner, who intervened immediately. He ordered the removal of disparaging intertitles before a public release would be permitted, thus delaying the film's release. Hayward's irritation with the adjournment was public. Believing they were disgruntled for not being asked to be involved, Hayward reported to newspapers that the Censor had paid too much attention to the Ringatū's "imagined grievances" (Hayward, as cited in Blythe, 1994, p. 39). The secretary of the Whakatāne Film Society complained to his local MP that "directors emphatically object to natives viewing film [because] they consider it grossly unfair to allow the Censor to be influenced" (as cited in Binney, 1995, p. 553). Highlighting these comments in today's context underlines the lack of care and understanding about cultures by non-Māori filmmakers, which indeed reinforced the brazen institutional racism at play in film production. It also highlights the responsibility of contemporary Māori filmmakers to ensure portrayals are culturally appropriate rather than cinematically predictable.

The turnaround for implementing the Censor's recommended changes was less than 10 days. The Te Kooti Trail was released. The parts of The Te Kooti Trail that so offended the Ringatū could not have been overly important to the film, as they were swiftly excised. Ironically, the controversy served the film's commercial appeal. The Te Kooti Trail's marketing focus was changed from offering a slice of "authentic" New Zealand history to emphasising the government's failure to stop it. One advertisement stated the film had been "Stopped! By the NZ Censor because of its Amazing Historical Realism-Then released because it proved to be the truth." Another accentuated in capital letters "NOT FICTION-FILMED FACTS . . AN EPIC OF THE KING OF OUTLAWS" (Binney, 1995, p. 554; Dennis, 1996, p. 202; Elmberg, 1956, p. 250). Highlighting the controversy sparked much public interest prior to the film's release. Ironically, The Te Kooti Trail was the first New Zealand film to benefit from "poor press", and consequently became Hayward's most successful film. Although his career spanned another 50 years, he did not see such controversy or public interest again.

\section{Te Arawa's resistance}

Te Arawa's long collective absence from film for nearly 40 years was the second instance of Māori resistance in New Zealand film history. A year after the release of The Te Kooti Trail, resistance to film ventured to Rotorua. With its panoramic lake vistas, rolling hills and geothermic activity, Rotorua was a haven for "Māoriland" film production (prior to the turn of the century, Australian newspaper reporters called New 
Zealand "Māoriland" after the Indigenous people; Blythe, 1988, 1994). Films produced in Rotorua prior to Under the Southern Cross (Collins, 1928) included Loved by a Maori Chieftess (Méliès, 1913c), How Chief Te Ponga Won His Bride (Méliès, 1913b), the various Hinemoa films (Méliès, 1913a; Tarr, 1914), A Maori Maid's Love (Longford, 1916a), The Mutiny of the Bounty (Longford, 1916b), The Betrayer (B. Smith, 1921), The Adventures of Algy (B. Smith, 1925) and Rewi's Last Stand (Hayward, 1925). In addition to the idyllic background, Rotorua offered the Te Arawa people, the local iwi who thrived on extending the richest of manaakitanga on and off screen. When necessary, they happily provided native ambience by appearing as extra cast-as seen in Adventures of Algy-and as a consequence of their long history of hospitality and tourism, were hosts behind the scenes. In this regard, Te Arawa should be acknowledged as the most remarkable of contributors to Māoriland films in the silent period.

Under the Southern Cross, also known as Taranga and as The Devil's Pit, should not be confused with the film bearing the same name directed by Gustav Pauli released in the same year. American Alexander Markey's film was quite distinctive, particularly in terms of behind the scenes. For instance, Markey continuously failed to submit the required footage to the producers and exceeded the budget (Martin \& Edwards, 1997; Mita, 1996). His many other transgressions were noted as a variety of "scandals, stories, objects, debts, thefts and texts" (Limbrick, 2007, p. 249) that led to his eventual dismissal from the film. Merata Mita (1996) identified that the damage extended to serious cultural misdemeanours affecting the Te Arawa cast. During the production of Under the Southern Cross, Markey insisted that the cast perform actions against personal tikanga and tapu, such as using flour in their hair to age the characters. To Māori, the head is the most tapu part of the body. Food, on the other hand, is noa, its opposite. In the simplest of terms, placing food on the head disrupts a very important personal tapu, the spiritual force field that protects the individual from negative energies. Mita (1996) believed the "counter-tapu" acts caused cast members to be struck down with debilitating illnesses (p. 42). Furthermore, very precious cultural taonga loaned by $\mathrm{Te}$ Arawa as props were stolen. When producers expelled him, Markey took the taonga back to the United States. Te Arawa were insulted by Markey's arrogance and abuse of their culture and hospitality, and he was strongly urged not to return to Rotorua (Mita, 1996). Te Arawa's refusal to host Markey forced him to relocate Hei Tiki (Markey, 1930) to Taupō (Limbrick, 2010; Mita, 1996), a proximate stand-in.

Despite the misdemeanours of Under the Southern Cross, Markey received funding and support from the New Zealand government for his dream concept, Hei Tiki (Limbrick, 2010). Furthermore, he received a special pass, known as the government's "seal of approval", previously assigned to New Zealand's most distinguished guests only (Limbrick, 2010). Aware of his previous dealings with the Ringatū and Te Arawa, it is said that MP Apirana Ngata paid close attention to Markey (Limbrick, 2010, p. 148). An incredibly counter-tapu act he demanded in Hei Tiki was for the main female protagonist, Mara, to walk over the backs of the village tamatāne, who were lying face down on the ground, as she was presented to the hapu for her coming-of-age celebration. The strange and exotic action would have appealed to international audiences; however, in actuality, wāhine are not permitted to step over tāne, for reasons beyond courtesy and modesty. The tenetene is the conduit through which life travels from the spiritual world to the physical world. Tenetene are so highly tapu that they can drain tapu from men and draw it into the woman's body (Collard, 2006, p. 318; Hanson, 1982, pp. 350, 356-357), and potentially leave them sterile.

The resistance posed by Te Arawa following Markey's intrusion had a lasting effect. Individual Te Arawa actors continued to act 
in films on their own accord, as an individual, professional choice. However, as a collective, the iwi did not participate in film production for the 38 years between the filming of Under the Southern Cross and the musical comedy Don't Let It Get You (O'Shea) in 1966. They returned in force to support the film's featured entertainer, Howard Morrison, Te Arawa's own entertainer extraordinaire. After the mamae, however, film production was for the most part unnecessary for Te Arawa, as tourists flocked to the booming geothermal wonderland anyway. Te Arawa's absence was a resistance because they chose to exercise their tino rangatiratanga by deciding, on their own terms, when they would participate in film production and for whom.

\section{Silent resistance in New Zealand film history}

\section{The Seekers}

The Seekers is a Māoriland story based on fictional explorer Phillip Wayne, who, while on reconnaissance, stumbles upon an underground burial chamber, thus angering the locals. For his ignorance, Wayne is forced to duel with a local warrior. They race through surrounding forests, over hills and rocks, and swim the lake to demonstrate their physical prowess, and Wayne prevails. As a peace treaty, Chief Hongi Tepe gifts him a piece of land to settle on, and ultimately opens the gateway for British immigration. His triumph attracts the local women, including Tepe's dazzling wife, Moana. Wayne is eventually married to God-fearing Marion. Regardless, Moana pursues him, and ensnares him in a torrid affair, witnessed by a loyal member of Tepe's tribe. Tepe kills Moana. The peace treaty between Māori and settlers ends, and a night battle between taiaha-wielding Māori and gun-bearing settlers ensues. Wayne and Marion sacrifice themselves in a fiery battle, orphaning their baby son, who is hidden in a burrow next to their now dilapidated house. The next day, Tepe finds the boy, and devotes himself to raising the first Pākehā in the tribe.

\section{A silent Māori audience}

Silence, as I will convey in the following sections, is a contrapuntal resistance. The seed of this article is the silent response to The Seekers, which occurred when it was viewed by one of four rōpū whānau for the audience study component of my doctoral thesis (Wilson, 2013). A critical component of the thesis was the specific hapu responses to a selection of films in which Māori were featured characters. Māori screen audience studies are uncommon (Poihipi, 2007; J. Smith, 2016; Wilson, 2013), and therefore the audience component was the most important part of the project. Members of Ngāti Kawa (comprising three cousins $[40+]$ and three nieces $[20+]$, five females and one male), one of my two predominant hapū, viewed The Seekers, a post-sound synchronicity film, and refused to verbally respond. Ngāti Kawa are the people from Oromāhoe marae, situated on the cusp of Ngāti Hine and Ngā Puhi, and located next to the trenches used in the battle of Ōhaeawai during the New Zealand Wars. Also notable is that Ngāti Kawa are the kaitiaki of Waitangi marae. This is notable because the sites for which Ngāti Kawa are responsible, and on which they are located, are sites of constant battle and resistance. Such resistance contributes to their distinct worldview. As the silent response to The Seekers conveys, location and political background influences perspectives on film.

Silent resistance to film by other audiences in the past may have been considered unusable or invalid. During the screening of The Seekers, there were deep guttural sounds, tongue clicks, swearing and heckling by the whānau, as expected. As had been the routine throughout the wānanga, I readied myself with a pad, pen and digital voice recorder to prepare for our whakawhiti kōrero once the closing credits commenced. However, the whānau 
immediately proceeded to tidy the wharenui. A silent response is an unusual or undocumented reaction to film, but as Mead (1984) stated, "stony silence" is likely to follow poor performances. Discarding the reaction would mean there would be no trace of this kind of resistance to The Seekers. To deny the overt rejection of The Seekers would undermine the group's tino rangatiratanga and their right to respond in their own way, which was critical to the way forward for a distinctively Māori film studies trajectory. Being silent and removing themselves from engaging in a discussion is also an expression of the rights of volunteers to research. Silence in the instance of the whānau resisting The Seekers should not be misperceived as passivity, but as an active choice not to engage. But why this response to The Seekers?

\section{Counterpointing stereotypes in The Seekers}

Film scholars Helen Martin and Sam Edwards (1997) identified three stereotypes in The Seekers: cannibals, evil witch doctors and dusky maidens. To explore these stereotypes, the intensity of the audience's rejection of the film and the silent response, I refer to post-colonial theorist Edward Said. Said's primary contribution to comparative literature was to divulge otherwise overlooked effects of colonisation. His seminal text Orientalism (Said, 1978), a critical analysis of the West's condescending representation of the East in literature, led to Culture and Imperialism (Said, 1993), in which he borrowed contrapuntalism from music as an analysis tool. The contrapuntal or counterpoint analyses exposed political and racial injustices by arranging the story's main narrative within the treble stave, and tabulated actual local historical affairs onto the bass stave. His best known contrapuntal analyses are of famous authors who denied Indigenous people presence and agency, generally in their native settings. Using contrapuntalism to unpack the stories forces a more conscious and critical re-reading, and I have adopted this for the reading of The Seekers to distinguish between the stereotypes identified by Martin and Edwards and mātauranga Māori concepts, kaitangata, tohunga and māreikura. I have done so to convey the level of counter-tikanga in the production, likely to have caused the rejection of The Seekers and silent resistance.

\section{Counterpointing cannibalism}

As mentioned previously, film historians Helen Martin and Sam Edwards (1997) identified stereotypes from The Seekers: cannibals, evil witch-doctors and dusky maidens (p. 53). Early on in The Seekers, Wayne explores inside a cave, and is shocked to stumble upon a cluster of skeletons. The bare bones unhinge Wayne and viewers, underlining the supposed moral instability of the land's inhabitants. Although the scene mystifies Polynesian burial practices, the bones evoke cannibalism. Some anthropologists had written that the presence of bones was evidence of cannibalism, which influenced Annakin's display of Māori in The Seekers (Beaglehole, 1955, 1962; Begg \& Begg, 1966; Darwin, 1979; McNab, 1917; Parkinson, 1784). Historian Paul Moon (2008) wrote that European people have particular anxieties about cannibalism, manifest in the works of European writers in the 18th and 19th centuries. Hence, it was important to insinuate cannibalism during the establishment scenes, to build on the predominantly European audience's anxieties that primitive people-such as Māori-eat people.

Concealing bones in such chambers, particularly of chiefs, was common until the missionaries came to Aotearoa. At least a year after death, the hahunga ritual took place, when the bones were retrieved from the chamber, cleaned, painted with red ochre and relocated to a secret place so as not to be desecrated by nemeses (Hanson \& Hanson, 1983; Mead, 2003; Salmond, 1975). To Māori, a great insult is the defilement of sacred places, particularly 
urupā (Joseph, 1999); thus, every caution to protect the bones from enemies was taken. Presenting scenes such as these serves to capitalise on the audience's fear of unknown cultural philosophies and the evocation of cannibalism, and propels the audience into a sense of unease about Māori for the remainder of the film.

Martin and Edwards (1997) marked cannibalism as a stereotype in the film; however, it is unrealistic to suggest cannibalism is present in any other evidence besides the bare bones in this scene. Regardless, I will briefly counterpoint cannibalism with kaitangata or the flesh-eating ritual as it does require rationalisation in film history. Kaitangata was largely a metaphorical ritual, despite anthropologists' and ethnographers' claims it was for recreation or sustenance (Jennings, 2011). If one chief vanquished another, it was tika for him to consume the mana of the opposing chief, signified by the ingestion of a small portion of his flesh (Jennings, 2011). In a Western context, kaitangata is viewed as cannibalism. Yet the very definition of cannibalism pivots on the consumption of the same flesh as oneself as food. This does not reflect the purpose of the kaitangata ritual. The insinuation or anxiety towards cannibalism, and indeed fear of peculiar burial rituals, could be features causative of the Ngāti Kawa whānau not wanting to respond to The Seekers. The cannibal stereotype is offensive enough for the whannau to reject the film and respond with silence, as it renders the history cliché.

\section{Counterpointing evil witch doctors}

In The Seekers, the character Awarua represents the evil witch doctor-the second stereotype identified by Martin and Edwards. Polk (1997) wrote about the evil witch doctors in low-budget American cinema stemming from fantasies about Haitian voodoo practices. Cinematic evil witch doctors in zombie movies in particular have raised anxieties about their possession of innocent white protagonists (Clammer, 2016).
These components were woven into the Awarua characterisation that perpetuates the perception of Māori belief systems and philosophies as bizarre and heathen, as he is stylised to appear eccentric. Most often wielding a patu pounamu, Awarua has wild, fuzzy white hair, and babbles senselessly in untranslated te reo. He is the only person unfazed by Wayne's arrival, and openly shows suspicious of him via bemused facial expressions. Further, when Awarua appears in the frame, he is accompanied by minor chords in the sound design, enshrouding him in ambiguity and antagonism, and adding to an already dubiously stylised caricature.

As there is some basis for this character in te ao Māori, I counterpoint the evil witch doctor with tohunga. Tohunga possess the knowledge of the gods, and consequently, anxieties about them among non-Māori are common (T. Smith, 2008). Shunned by non-Māori for their work in the spiritual paradigm, tohunga were accused of interfering with Western medicine, and risking Māori lives by not dealing with the “unsanitary” Māori lifestyle (Stephens, 2001). In answer to these concerns, the government legislated the Tohunga Suppression Act (1907), designed to neutralise the authority of both tohunga and powerful Māori spiritual leaders. Tūhoe prophet Rua Kenana, for example, rose in influence at the time the Act was passed, with a community of at least 1,000 people with him at Hiruharama Hou, the New Jerusalem. Kenana, and indeed Māori leaders, posed a threat to nationalism, because re-empowering Māori-who greatly outnumbered Pākehā at the time-meant they could return to presettlement autonomy and potentially overthrow the Crown. Along with many tohunga, Kenana was incarcerated to disempower a conceivable uprising. The Act was repealed in 1962, but by that time tohunga had been estranged from, and ridiculed by, their own communities and whānau for decades. As tohunga were also the custodians of oral histories, cultural loss was severe. The Tohunga Suppression Act was indeed a blight across all Māori communities. It 
could be that the Awarua character serves as a painful reminder of tohunga prohibition, rejection and extreme cultural loss. The stereotypical representation of a character such as Awarua makes the rejection of, and silent resistance to, The Seekers by the whānau understandable. Exploiting such stereotypes is clearly intended to fascinate international audiences who desire to see their pre-existing ideas about Polynesian peoples, informed by Western texts and art historical depictions, personified.

\section{Counterpointing the dusky maiden}

The last stereotype I will counterpoint is the dusky maiden character Moana, which I contrast with the humble, selfless māreikura (Simpson, 2006). The exaggeration of the dusky maiden, as the following analysis will show, could have been sufficient in itself to cause the rōpū whānau to resist discussing The Seekers, particularly as the audience were predominantly wāhine. Moana's primary function was to appeal to Eurocentric male fantasies about sexually available Polynesian women (Simmons, 1998). Producer George Brown described her as "the temptress whom the white settler cannot resist" (as quoted in Limbrick, 2010, pp. 188-189). Reportedly, the demand for Moana's indecent performances put Māori actresses off the role (Limbrick, 2010). German-Javanese actress Laya Raki was by no means dusky, but her portrayal is an archetypal cinematic dusky maiden in her other characteristics and styling: scantily clad, conventionally more beautiful than her duskyskinned counterparts, a comely demeanour and a lustful appetite. When introduced, Moana is subdued; draped in an ornate korowai, she appears the epitome of māreikura-a woman of status-standing nobly next to Tepe, her husband. In this, the performance is of a māreikura high-born, regal and groomed from birth (Simpson, 2006). However, the integrity of this portrayal is immediately betrayed. Her momentary side glance at Wayne with a cocked eyebrow and smirk disrupts the stately façade, and exposes Moana's lasciviousness. Wayne gulps and sweats with discomfiture. Moments later, Wayne unsuccessfully fishes at the lake, where a topless Moana emerges from the water with an impaled fish; both her body and the fish are for his consumption. Later, they rendezvous in the bush, where Moana's pursuit of Wayne is realised, and they fall into a carnal affair, witnessed through the vines by a loyalist who reports her treachery to the now merciless Tepe. These scenes are far from the stateliness Moana presented to the audience a short time prior.

The Moana character was required to perform two unsettling counter-tikanga acts. One was to seduce Wayne as indicated above, and the other was to perform an erotic dance for the tribe's prisoners of war. Film historian Peter Limbrick (2010) sketches out the dance sequence:

Hongi Tepe's men begin singing and chanting as Moana appears clad in a piupiu ... and a feathered strapless, and backless brassiere. Moana's dance then begins and continues for about two minutes, during which she runs around the perimeter of warrior men, waving her arms, shaking her upper body, and often falling to the ground to gyrate before the men. The camera usually holds her in long shot ... although she often lunges toward it, especially as the pace of the music picks up and the dance becomes more overtly erotic; she shakes her hair and breasts in medium shot framing. (p. 192)

Limbrick's (2010) description of the scene is useful because it highlights precisely what the dance sequence is at a visual level, rather than what it is culturally not. Here I briefly expand beyond Limbrick's outline of the dance by counterpointing the choreography with haka. Kaioraora are dissent haka that threaten to eat someone's mana and aim to offend, insult and vent frustration (Papesch, 2009). The supposed intent of Moana's dance was essentially to 
show dissent to their captives of war. Moana emerges from behind Tepe, performs a pūkana with a wiri salute for a couple of beats, which concludes the haka content. A hula-jazz concoction-consisting of split kicks and shoulder rolls-ensues (McDonnell, 1998). Although Moana's choreography was meant to show disdain for their tribal enemies, the moves she uses are erotic, and are therefore closer to a pōtēteke, so named because "teke" refers to female genitalia. Pōtēteke are extremely athletic, gymnastic and acrobatic because they can include somersaults (Love, 1952), none of which are present in the choreography.

Beyond the problematical choreography, it must be remembered that Moana is a māreikura, and in this case the wife of a chief, so her mana is equal to his. Neither kaioraora nor pōtēteke are recorded anywhere as being performed by women of such status, as her mana is interchangeable with the chief's. She is highly protected to ensure her ongoing "specialness" (Simpson, 2006, p. 2). A contrapuntal analysis of the dance shows it is not haka, and Moana's overall performance is counter-māreikura. Moana is worthy of the audience's rejection. As I have only lightly sketched here, Moana is an impressionable character who counters acceptable behaviours of māreikura, and thus can easily vex Māori viewers beyond words, as was the case with Ngāti Kawa.

\section{Conclusion}

Resistance is part of New Zealand film history. In this article, I have described three instances of collective Māori resistance to New Zealand films released between 1927 and 1954. The first was the protest about The Te Kooti Trail to the Film Censor by the Hāhi Ringatū. The second was Te Arawa's long absence from film production as a result of a mischievous foreign director. The third was Ngāti Kawa's refusal to engage in a discussion about The Seekers, a response to a historical film by a contemporary audience. I employed contrapuntalism to problematise the stereotypes identified by Martin and Edwards (1997) that were likely causative of the whānau rejecting the film. The contrapuntal analysis of the stereotypes briefly explained important mātauranga Māori concepts that would otherwise continue to be misconstrued or omitted had they not been woven in here. As I sum up this article, I remember my Ngāti Kawa whānau who actively exercised their mana motuhake by not verbally responding to The Seekers-who spoke no words, which said so much. My thoughts are with my Ngāi Taiwhakāea whānau, sitting quietly on the corner of Golflinks and Taiwhakāea Roads, drawing attention to land injustices in Pāroa. Choosing not to speak during both these reallife resistances should not be confused with a lack of engagement or presence. Resistance is part of being Māori.

\section{Acknowledgements}

To the Ngāti Kawa whānau who literally said nothing about The Seekers, which sent me on the adventure of exploring the silent Māori audience and resistance to film throughout New Zealand film history: Kahore ngā kupu, tino nūnui te kōrero, e te whānau. Ngā mihi rawa atu koutou. This article was supported by the Māori and Pacific Post-Doctoral Fellowship at the School of Art \& Design, Department of Creative Technologies, at the Auckland University of Technology. Ngā Pae o te Māramatanga Conference Award Grant (2016) also generously contributed to the initial version of this article.

\section{Glossary}

$\begin{array}{ll}\text { amine } & \text { amen } \\ \text { ariki } & \text { paramount chief } \\ \text { Hāhi Ringatū } & \begin{array}{l}\text { Church of the Upraised } \\ \text { Hand }\end{array}\end{array}$




\begin{tabular}{|c|c|c|c|}
\hline \multirow{2}{*}{$\begin{array}{l}\text { hahunga } \\
\text { haka }\end{array}$} & second mourning & papakāinga & home-ground \\
\hline & posture dance & patu pounamu & greenstone hitting \\
\hline hapū & subtribe, to be pregnant & & weapon \\
\hline hīkoi & walk, march & piupiu & flax garment used in \\
\hline hui & meeting & & kapa haka \\
\hline hupe & snot & pōtēteke & a sexual haka \\
\hline $\begin{array}{l}\text { ihi } \\
\text { iwi }\end{array}$ & $\begin{array}{l}\text { excitement, power } \\
\text { tribe, bones }\end{array}$ & pūkana & $\begin{array}{l}\text { a wild stare, dilation of } \\
\text { the eves }\end{array}$ \\
\hline kaioraora & venting haka & raupatu whenua & land confiscation \\
\hline \multirow{3}{*}{$\begin{array}{l}\text { kaitangata } \\
\text { kaitiaki }\end{array}$} & flesh eating & rōpū & group, party of people, \\
\hline & guardian, minder; & & organisation \\
\hline & $\begin{array}{l}\text { custodian over } \\
\text { natural resources }\end{array}$ & taiaha & $\begin{array}{l}\text { close quarters combat } \\
\text { weapon }\end{array}$ \\
\hline \multirow{3}{*}{$\begin{array}{l}\text { kapa haka } \\
\text { kororia ki tou ingoa } \\
\text { tapu }\end{array}$} & Māori performing arts & tamatāne & adolescent boys \\
\hline & glory to your holy name & tāne & men \\
\hline & & taonga & precious possessions \\
\hline \multirow{6}{*}{$\begin{array}{l}\text { koroua } \\
\text { korowai } \\
\text { mamae } \\
\text { mana }\end{array}$} & grandfather, old man & tapu & sacred, prohibited, \\
\hline & traditional cloak & & restricted \\
\hline & pain, ache & te ao Māori & Māori worldview \\
\hline & $\begin{array}{l}\text { prestige, status, } \\
\text { authority, influence, }\end{array}$ & Te Arawa & $\begin{array}{l}\text { canoe and tribe based in } \\
\text { Rotorua }\end{array}$ \\
\hline & integrity; honour, & teke & female genitals \\
\hline & respect & tenetene & vagina \\
\hline \multirow{3}{*}{$\begin{array}{l}\text { manaakitanga } \\
\text { mana motuhake }\end{array}$} & showing hospitality & te reo Māori & Māori voice, language \\
\hline & separate identity, & tika & correct, right \\
\hline & self-government & tikanga & correct procedures/ \\
\hline \multirow[t]{2}{*}{ marae } & tribal meeting grounds; & & conduct \\
\hline & village common & tino rangatiratanga & self-determination \\
\hline \multirow[t]{2}{*}{ māreikura } & women of high birth or & tīpuna & ancestor \\
\hline & nobility & tohunga & expert \\
\hline \multirow{3}{*}{$\begin{array}{l}\text { mātauranga } \\
\text { Ngā Puhi }\end{array}$} & knowledge, wisdom & Tūhoe, Ngāi & inland Eastern Bay of \\
\hline & largest tribe, located in & & Plenty tribe \\
\hline & the Far North & urupā & burial ground, cemetery \\
\hline \multirow[t]{3}{*}{ Ngāti Kawa } & a subtribe of Ngā Puhi & wāhine & women \\
\hline & based in Oromāhoe in & wairua & the soul or spirit \\
\hline & the Far North & wana & thrill \\
\hline \multirow[t]{2}{*}{ Ngāti Pūkeko } & an Eastern Bay of & wānanga & intense learning \\
\hline & Plenty subtribe & wehi & awe, fear, dread \\
\hline \multirow[t]{4}{*}{ noa } & not sacrosanct, having & whakawhiti kōrero & discussion \\
\hline & no restrictions/ & whānau & family; nuclear/ \\
\hline & prohibitions; free & & extended family \\
\hline & from tapu & whanaunga & relation \\
\hline \multirow[t]{2}{*}{ Pākehā } & Caucasian New & wharenui & meeting/main house \\
\hline & Zealander & wiri & tremble, shudder \\
\hline
\end{tabular}




\section{References}

Annakin, K. (Dir.). (1954). The seekers [Motion picture]. England: Universal-International.

Beaglehole, J. C. (1955). The journals of Captain James Cook on his voyages of discovery: Volume I -The voyage of the Endeavour 1768-1771. Cambridge, England: Cambridge University Press for the Hakluyt Society.

Beaglehole, J. C. (1962). The Endeavour journal of Joseph Banks 1768-1771. Sydney: Trustees of the Public Library of New South Wales in association with Angus and Robertson.

Begg, A., \& Begg, N. (1966). Dusky Bay. Christchurch, New Zealand: Whitcombe and Tombs.

Binney, J. (1995). Redemption songs: A life of Te Kooti Arikirangi Te Turuki. Auckland, New Zealand: University of Auckland Press and Bridget Williams Books.

Blythe, M. J. (1988). From Maoriland to Aotearoa: Images of the Maori in New Zealand film and television (Unpublished doctoral dissertation). University of California, Los Angeles, California.

Blythe, M. (1994). Naming the other: Images of the Maori in New Zealand film and television. Metuchen, NJ: Scarecrow Press.

Clammer, P. (2016). Haiti: The Bradt travel guide. Chalfont St. Peter, England: Bradt Travel Guides.

Clark, A. (Dir.). (2006). The King Boys [Motion picture]. New Zealand: Chameleon Films.

Collard, J. (2006). Spiral women: Locating lesbian activism in New Zealand feminist art, 19751992. Journal of the History of Sexuality, 15(2), 292-320. http://doi.org/cv5mdw

Collins, L. (Dir.). (1928). Under the Southern Cross [Motion picture]. United States: Universal Pictures.

Darwin, C. (1979). The journal of a voyage in $H$. M. S. Beagle [Facsimile reproduction]. Surrey, England: Genesis Publications in association with Australia and New Zealand Book Co.

Dennis, J. (1996). A time line. In J. Dennis \& J. Bieringa (Eds.), Film in Aotearoa/New Zealand (pp. 199-235). Wellington, New Zealand: Victoria University Press.

Elmberg, J. E. (1956). Islands of tomorrow. London, England: Rupert Hart-Davis.

Hanson, F. A. (1982). Female pollution in Polynesia. Journal of Polynesian Studies, 91, 335-381.

Hanson, F. A., \& Hanson, L. (1983). Counterpoint in Māori culture. London, England: Routledge and Kegan Paul.
Hayward, R. (Dir.). (1925). Rewi's last stand [Motion picture]. New Zealand: Frontier Films.

Hayward, R. (Dir.). (1927). The Te Kooti trail [Motion picture]. New Zealand: Whakatane Films.

Jennings, W. (2011). The debate over "kai tangata" (Māori cannibalism): New perspective from the correspondence of the Marists. Journal of Polynesian Society, 120(2), 129-147.

Jonathan, M. (Dir.). (2006). Hawaikii [Motion picture]. New Zealand: Chain of Title Films.

Joseph, R. (1999). Māori customary laws and institutions: Crimes against the person, marriage, internment, theft. Laws and Institutions for Aotearoa/New Zealand, Te Matahauraki Research Institute, University of Waikato, Hamilton. Retrieved from http://lianz.waikato. ac.nz/PAPERS/Rob/Custom\%20Law.pdf

Ka'ai, T. (2008). Ngoingoi Pēwhairangi: An extraordinary life. Wellington, New Zealand: Huia.

Limbrick, P. (2007). The flotsam and jetsam of film history: Hei Tiki and post-colonial rearticulations. Journal of Visual Culture, 6(2), 247-253. http://doi.org/bhjbh2

Limbrick, P. (2010). Making settler cinemas: Film and colonial encounters in the United States, Australia, and New Zealand. New York, NY: Palgrave Macmillan. http://doi.org/fth9tb

Longford, R. (Dir.). (1916a). A Māori maid's love [Motion picture]. Australia: Vita Film Corporation.

Longford, R. (Dir.). (1916b). The mutiny of the Bounty [Motion picture]. Australia: Crick and Jones.

Love, R. (1952, Winter). Sport among the Maori people. Te Ao Hou: The New World, 1, 60-64.

Markey, A. (Dir.). (1930). Hei tiki [Motion picture]. United States: Alexander Markey Productions.

Martin, H., \& Edwards, S. (1997). New Zealand film, 1912-1996. Auckland, New Zealand: Oxford University Press.

McDonnell, B. (1998). All virgin soil and it don't belong to noone? Notes on the representation of nineteenth century New Zealand feature films. New Zealand Journal of Media Studies, 4(2), 16-25.

McNab, R. (1917). From Tasman to Marsden: A history of Northern New Zealand from 1642-1818. Dunedin, New Zealand: Wilke.

Mead, S. M. (1984). Nga timunga me nga paringa o te mana Maori/The ebb and flow of mana Maori and the changing context of Maori art. In S. M. Mead (Ed.), Te Maori: Maori art from the New Zealand collections (pp. 20-36). Auckland, New 
Zealand: Heinemann and American Federation of Arts.

Mead, H. M. (2003). Tikanga Māori: Living by Māori values. Wellington, New Zealand: Huia.

Méliès, G. (Dir.). (1913a). Hinemoa [Motion picture]. United States: Star Film Company.

Méliès, G. (Dir.). (1913b). How Chief Te Ponga won his bride [Motion picture]. United States: Star Film Company.

Méliès, G. (Dir.). (1913c). Loved by a Māori chieftess [Motion picture]. United States: Star Film Company.

Mita, M. (Dir.). (1980). Bastion Point: Day 507 [Motion picture]. New Zealand: A Mita, Narbey, Pohlmann Production.

Mita, M. (1996). The soul and the image. In J. Dennis $\&$ J. Bieringa (Eds.), Film in Aotearoa/New Zealand (pp. 36-56). Wellington, New Zealand: University of Victoria Press.

Moon, P. (2008). This horrid practice: The myth and reality of traditional Maori cannibalism. Auckland, New Zealand: Penguin Books.

O'Shea, J. (Dir.). (1966). Don't let it get you [Motion picture]. New Zealand: Pacific Films.

Papesch, T. (2009) Te puoro reo o kui mā, o koro mā waiata tawhito: Traditional Māori music. Sound Ideas, 8(1), 4-13.

Parkinson, S. (1784). A journal of a voyage to the South Seas in his Majesty's ship the Endeavour. London, England: Dilly and Phillips.

Pauli, G. (Dir.). (1927). The romance of Hinemoa [Motion picture]. England: Gaumont-British Picture Corporation.

Poihipi, V. (2007). The impact of Māori television on being Māori: A geographical approach. MAI Review, 1, 1-21.

Polk, P. A. (1997). Haitian Vodou flags. Jackson, MI: University Press of Mississippi.

Rich, A. (1993). The dream of a common language. New York, NY: Norton. (Original work published 1978)
Said, E. (1978). Orientalism. New York, NY: Pantheon. Said, E. (1993). Culture and imperialism. London, England: Chatto and Windus.

Salmond, A. (1975). Hui: A study of Maori ceremonial gatherings. Wellington, New Zealand: Reed.

Simmons, L. (1998). Distance looks our way: Imagining New Zealand on film. In D. Verhoeven (Ed.), Twin peeks: Australian and New Zealand feature films 1890s-1999 (pp. 39-49). Melbourne, Australia: Damned.

Simpson, A. (2006). Puhi: Memories and experiences in their ceremonial role in traditional and contemporary Māori worlds. MAI Review, 1, 1-15.

Smith, B. (Dir.). (1921). The betrayer [Motion picture]. Australia: Beaumont Smith's Productions.

Smith, B. (Dir.). (1925). The adventures of Algy [Motion picture]. Australia: Beaumont Smith's Productions.

Smith, J. (2016). Māori television: The first ten years. Auckland, New Zealand: Auckland University Press.

Smith, T. (2008). Tohu and Māori knowing. In J. S. Te Rito \& S. M. Healy (Eds.), Proceedings of the Traditional Knowledge Conference 2008 Te Tatau Pounamu: The Greenstone Door; Traditional Knowledge and Gateways to Balanced Relationships, Auckland (pp. 266270). Auckland, New Zealand: Ngā Pae o te Māramatanga.

Stephens, M. (2001). A return to the Tohunga Suppression Act 1907. Victoria University of Wellington Law Review, 32, 437-462.

Tarr, G. (Dir.). (1914). Hinemoa [Motion picture]. New Zealand: Hayward Pictures.

Visweswaran, K. (1994). Fictions of feminist ethnography. Minneapolis, MI: University of Minnesota Press.

Wilson, J. K. T. (2013). Whiripapa: Tāniko, whānau and kōrero-based film analysis (Unpublished PhD thesis). University of Auckland, New Zealand. 